\title{
THE POTENTIAL OF CD4+ REGULATORY T CELLS FOR THE THERAPY OF AUTOIMMUNE DISEASES
}

\author{
Churov $A V^{1} \bowtie$, Siutkina $A l^{2}$, Mamashov $K Y^{3}$, Oleinik $E K^{1}$ \\ ${ }^{1}$ Karelian Research Centre of the Russian Academy of Sciences, Petrozavodsk, Russia \\ 2 Perm State Pharmaceutical Academy, Perm, Russia \\ ${ }^{3}$ Kemerovo State Medical University, Kemerovo, Russia
}

\begin{abstract}
Despite the considerable progress in the therapy of autoimmune pathologies, the existing methods are associated with the risk of serious adverse events. We think that regulatory $T$ cells hold great promise for the therapy of disorders caused by a breakdown in immunological self-tolerance. This article aims at estimating the possible challenges facing Treg-based clinical approaches and offers solutions to the technical issues associated with the use of these cells in the therapy of autoimmune diseases
\end{abstract}

Keywords: regulatory T cells, FOXP3, autoimmune disease, immunotherapy, cell therapy, CAR-Treg therapy, CRISPR/Cas9

Funding: the study was carried out under state order for Karelian Research Centre (ID 0218-2019-0083; Modification of transcription programs of regulatory $T$ cell differentiation in immunoinflammatory diseases and cancer). Its publication was sponsored by Prime Papers LLC.

Acknowledgements: the authors thank the Center for Precision Genome Editing and Genetic Technologies for Biomedicine (Moscow) for consultations.

Author contribution: Churov AV — article design, literature analysis, preparation of the manuscript draft and its final version; Syutkina Al — article design, the major contribution to literature analysis, preparation of the manuscript draft and its final version; Mamashov KY — article design, literature analysis, preparation of the manuscript draft and its final version; Oleinik EK — literature analysis, preparation of the manuscript draft and its final version.

$\triangle$ Correspondence should be addressed: Alexey V. Churov

Pushkinskaya, 11, Petrozavodsk, 186910; achurou@yandex.ru

Received: 25.11.2019 Accepted: 09.12.2019 Published online: 18.12.2019

DOI: $10.24075 /$ brsmu.2019.082

\section{ВОЗМОЖНОСТИ ПРИМЕНЕНИЯ СD4+-РЕГУЛЯТОРНЫХ Т-КЛЕТОК В ТЕРАПИИ АУТОИММУННЫХ ЗАБОЛЕВАНИЙ}

\author{
А. В. Чуров ${ }^{\otimes}$, А. И. Сюткина ${ }^{2}$ К. Ы. Мамашов ${ }^{3}$, Е. К. Олейник ${ }^{1}$ \\ 1 Федеральный исследовательский центр «Карельский научный центр Российской академии наук», Петрозаводск, Россия \\ 2 Пермская государственная фармацевтическая академия, Пермь, Россия \\ ${ }^{3}$ Кемеровский государственный медицинский университет, Кемерово, Россия
} На сегодняшний день достигнуты значительные успехи в терапии аутоиммунных патологий, однако существующие методы сопряжены с риском
возникновения тяжелых побочных эффектов. Применение Treg-клеток, на наш взгляд, представляет значительную перспективу в терапии состояний,
связанных с нарушением аутотолерантности. В работе дана оценка возможных трудностей использования клинического подхода на основе Ттеg-клеток и
предложены пути решения научно-технических задач, возникающих при применении Treg в терапии аутоиммунных заболеваний.

Ключевые слова: регуляторные T-клетки, FOXP3, аутоиммунное заболевание, иммунотерапия, клеточная терапия, CAR-Treg-терапия, CRISPR/Cas9

Финансирование: финансовое обеспечение исследований было осуществлено из средств федерального бюджета на выполнение государственного задания КарНЦ РАН, № 0218-2019-0083 (по теме «Изменение транскрипционных программ дифференцировки регуляторных Т-клеток при иммуновоспалительных и онкологических патологиях»). Спонсор публикации ООО «ПРАЙМ ПЕЙПЕРС».

Благодарности: авторы признательны Центру высокоточного редактирования и генетических технологий для биомедицины (Москва) за консультации в рамках подготовки статьи.

Информация о вкладе авторов: А. В. Чуров - дизайн статьи, анализ литературы, подготовка рукописи и финального варианта статьи; А. И. Сюткина дизайн статьи, основной вклад в анализ литературы, подготовку рукописи и финального варианта статьи; К. Ы. Мамашов - дизайн статьи, анализ литературы, участие в подготовке рукописи и финального варианта статьи; Е. К. Олейник - анализ литературы, участие в подготовке рукописи и финального варианта статьи.

$\bigotimes$ Для корреспонденции: Алексей Викторович Чуров

ул. Пушкинская, д. 11, г. Петрозаводск, 186910; achurou@yandex.ru

Статья получена: 25.11.2019 Статья принята к печати: 09.12.2019 Опубликована онлайн: 18.12.2019

DOI: $10.24075 /$ vrgmu.2019.082

Autoimmune diseases constitute a group of disorders arising from an imbalance in the immune system and a breakdown of self-tolerance mechanisms; these defects trigger a cascade of immune reactions against the body's own tissues.

At present, the treatment of choice for autoimmune disorders includes immunosuppressants, disease modifying antirheumatic drugs (DMARD) or genetically engineered therapeutics. However, these drugs are associated with the risk of serious adverse events. Regulatory $\mathrm{T}$ cells (Tregs) prevent immune responses to self-antigens, keep inflammation in check and thus block the development of autoimmune disorders by inducing and maintaining peripheral tolerance. Tregs constitute $3-5 \%$ of the peripheral CD4 ${ }^{+}$ T-cell population and can inhibit activation, proliferation and effector functions of $\mathrm{CD}^{+}$and $\mathrm{CD} 8^{+} \mathrm{T}$ cells, natural killer cells, B lymphocytes, and antigen presenting cells (APCs) [1]. In patients with autoimmune disorders, Treg levels are aberrant and Treg function is often weakened or impaired $[2,3]$. Experiments conducted in the mouse models of autoimmune diseases have demonstrated that adoptive transfer of Treg cells isolated from healthy mice has a good therapeutic effect [4]. The positive outcomes of preclinical trials have raised hopes for Treg-based approaches to the therapy of autoimmune diseases. 
The current state of research in the field and the limitations of the existing treatments for autoimmune disorders dictate the need for novel, highly specific, safe and effective approaches. We believe that Tregs can become the key component in the combination therapy of autoimmune disorders once the existing technical hurdles are overcome.

Based on the results of research and clinical trials, we offer our opinion on the prospects of harnessing Tregs for treating autoimmune diseases, assess challenges facing this approach and offer potential solutions.

\section{Regulatory T cells and suppressive mechanisms}

The key Treg markers are CD25 (a membrane antigen) and FOXP3 (an intracellular transcription factor). FOXP3 expression enables Tregs to exert their suppressive function [5], whereas CD25 is an IL2 receptor $\alpha$-chain, whose expression is correlated with proliferation and differentiation of Tregs [6].

Treg differentiation occurs in the thymus and peripheral tissues. After leaving the thymus, Tregs migrate into the blood stream and to peripheral lymphoid organs during the first 2 or 3 days of their life [7], where those with the CD4 ${ }^{+} \mathrm{FOXP3}^{-}$ phenotype can further differentiate into induced Tregs that actively express FOXP3 (CD4 $\left.{ }^{+} \mathrm{CD} 25^{+} \mathrm{FOXP3}^{+}\right)$.

Tregs exert their suppressive activity against immunocytes either via direct contact with the latter or by secreting bioactive molecules. There are 4 major mechanisms involved: a direct cytotoxic effect mediated by PD-1/PD-L1, OX40/OX40L and granzyme $\mathrm{B}$; induction of metabolic changes in the target cells (CD25, CD39, tryptophan); secretion of inhibiting cytokines (IL10, TGF $\beta$ and IL35); suppression of APCs (CD80 and CD86/ CTLA-4) [8].

\section{Clinical trials of Treg immunotherapies}

Clinical trials of Treg immunotherapies for autoimmune diseases began less than a decade ago. They sought to investigate technical challenges associated with Treg infusion, as well as to assess its safety and efficacy. In these clinical trials, a general approach is used: sorting of Treg cells, polyclonal expansion of Treg cells, Treg dose selection and infusion into patients. However, this approach does not account for the functional state of the used cells. The lack of stable FOXP3 expression and sustained suppressive activity are the common problems facing this approach to cell therapy and often the root cause of its low efficacy.

Published in 2012, a phase l/lla open-label multicenter clinical study known as CATS1 conducted in 4 groups of 20 patients with symptomatic refractory Crohn's disease has demonstrated the safety of Treg infusions [9] In February 2018, a double-blind placebo-controlled trial (TRIBUTE; NCT03185000) was started to assess the effect of $\mathrm{CD}^{+} \mathrm{CD} 25^{+} \mathrm{CD} 127^{\text {low }} \mathrm{CD} 45 \mathrm{RA} \mathrm{A}^{+}$Treg immunotherapy in patients with Crohn's disease resistant to at least two standard regimens.

Trials of Treg immunotherapy for type 1 diabetes mellitus (DM1) have produced favorable results. They began in 2014; the first trial was a phase I randomized study aimed at assessing the safety and feasibility of autologous Tregs isolated ex vivo from patients aged 7 to 18 years with a recently diagnosed DM1 [10]. This one-year-long trial did not reveal any serious adverse effects of Treg infusions and confirmed their safety. Besides, 8 of 12 patients participating in the trial showed signs of remission.

Another study carried out at the University of California and Yale University also investigated the efficacy and safety of Treg-based immunotherapy in adult patients with DM1; its results were published in 2015 [11]. Fourteen patients recruited for the study (6 females and 8 males aged 18-43 years) were distributed into 4 groups depending on the Treg dose. The participants received infusions of polyclonal Treg cells with the $\mathrm{CD} 4^{+} \mathrm{CD} 127^{\mathrm{lo} /-} \mathrm{CD} 25^{+}$phenotype in the amount of $0.05 \times 10^{8}$ to $26 \times 10^{8}$ cells. Up to $25 \%$ of the cells (from their peak amount) were retained in the peripheral blood of the recipients for the entire year following the adoptive transfer. No infusion-related or adverse effects were observed [11]. However, the optimal number of cells for infusion was not determined in the study and the effect of Treg therapy on the function of pancreatic $\beta$-cells was not established. A new phase II multicenter randomized double-blind placebo-controlled ongoing clinical trial (NCT02691247) is now attempting to fil this knowledge gap. The use of umbilical cord Treg cells with liraglutide and insulin therapies in adult/elderly patients with autoimmune diabetes is now being assessed in two phase I/II randomized open-label trials NCT03011021 and NCT02932826 (Central South University, Changsha).

In addition, two trials of immunotherapies with autologous polyclonal Treg cell infusions have already been initiated to test its efficacy and safety in patients with active pemphigus (NCT03239470) and autoimmune hepatitis (NCT02704338).

\section{Prospects and challenges of Treg immunotherapy}

The feasibility of Treg immunotherapy in patients with autoimmune pathology and the relative safety of this approach have been demonstrated in a few pilot clinical trials. Further research should focus on how immunosuppressive therapies can be combined with Treg infusions as some immunosuppressants affect Treg properties in a dose-dependent manner and can reduce the efficacy of these cells [12]. The use of Treg cells in combination with other therapies tailored to an individual patient holds the greatest promise for the future.

One of the major challenges impeding successful translation of Tregs into the clinic is production of stable Treg populations with sustained immunosuppressive activity. Currently, Tregs are isolated from peripheral blood cells and expanded ex vivo. Peripheral blood cells are heterogeneous and largely represented by the cells with induced FOXP3 expression.

Improving the specificity of Treg therapy is another important task. Treg functional activity is essentially antigen-specific. Antigen presentation leads to Treg activation and enhances the expression of membrane-bound inhibitory molecules that exert a suppressive effect on the target cell.

This phenomenon has been demonstrated in vivo for CTLA-4, the key inhibiting molecule of Treg cells. CTLA-4 is constitutively expressed by Tregs and T-effector cells [13]. Tregs control activation of $T$ effectors by blocking their access to the costimulating molecules CD80/86 on the APC membrane. CTLA-4 competitively blocks CD80/86 on the APC surface, binds and transports CD80/86 into the cell in the process of transendocytosis. Thus, Tregs can regulate the APC phenotype and effectively restrain the CD28-dependent activation of $T$ effectors. The competitive effect is achieved due to the fact that CTLA-4 expression on antigen-specific Treg cells is significantly higher than on T cells. The capture of CD80/86 by Treg is triggered by self-antigen presentation [13].

Clinical trials of Treg immunotherapy typically assess the effect of infusions of polyclonally expanded Treg cells with unknown antigen specificity. The majority of fused clones cannot effectively inhibit effector cells and suppress immune response. Besides, with polyclonal lymphocytes there is a high 
risk of adverse events, such as systemic immune suppression and reactivation of latent infection. Thus, clinical approaches based on polyclonal Treg cells are inevitably weak.

The past decade has seen the emergence of new highly effective therapeutic approaches based on adoptive cell transfer that can overcome the barriers preventing the use of Treg cells in the treatment of autoimmune diseases. Such approaches include genetically engineered effector $T$ cells expressing highly specific chimeric antigen receptors (CARs), as well as genome editing techniques, such as CRISPR/Cas9.

$T$ cells modified with CARs are successfully used in the therapy of some cancers. Such modification can also be effectively applied to Treg cells. CAR-Tregs have enormous potential: due to their antigen specificity, they can significantly improve the efficacy of treatment while causing very mild side effects [14]. In comparison with polyclonal Tregs, CAR-Tregs can bind to a specific protein on the membrane of the target cell. However, the manufacturing of CAR-Treg cells with sustained suppressive activity is technologically demanding. Besides, similarly to CAR-T cells, there is a risk of inducing the socalled cytokine storm and neurotoxicity. This is a very serious obstacle preventing the use of CAR-Tregs in the clinical setting. Moreover, identification and selection of targets for targeted therapy also pose a difficulty, especially in autoimmune diseases due to some aspects of their pathogenesis and the lack of knowledge of their etiology.

Previously, we mentioned that it is hard to produce a stable fraction of Treg cells. CRISPR/Cas9 (clustered, regularly interspaced, short palindromic repeats / CRISPR-associated protein) technologies or their advanced counterparts can offer a solution. The first preclinical studies of using CRISPR/ Cas9 for immunotherapy have yielded encouraging results. Attempts are being made to stabilize and enhance the functional activity of Treg cells. It is known that one of the major challenges is maintaining Treg viability ex vivo, which directly depends on the stability of FOXP3 expression. Here, the CRISPR/Cas9 technology can be recommended for the editing of genes participating in the regulation of transcription programs controlling Treg differentiation and the level of FOXP3 expression. A CRISPR/Cas9 system is highly specific due to small RNAs that guide Cas9 precisely into the target genome fragment [15]. In the case of Tregs and FOXP3, the CRISPR/Cas9 technology can also be employed for editing the epigenome. An experiment in the primary $T$ cells of mice has shown that a modification of a baseline technology, specifically the use of a mutant Cas9 without endonuclease activity (dead Cas9; CRISPR/dCas9), can induce the desired epigenetic changes promoting stabilization of Foxp3 expression [16].

\section{CONCLUSIONS}

The first results of clinical trials have demonstrated the relative safety of Treg-based therapy for autoimmune diseases. Research studies of the efficacy of polyclonally expanded Treg cells in patients with Crohn's disease, type 1 diabetes mellitus and some other autoimmune disorders have yielded inspiring results. However, the majority of clinical studies of Treg safety were conducted on small groups of patients and the approach itself has a few serious drawbacks, including its low antigen specificity in the first place. Further research should focus on the unsolved problems of adoptive Treg transfer, such as the search for the effective Treg dose, the improvement of the method's specificity by identification of novel molecular targets and the use of antigen-specific Treg infusions, stabilization of Treg immunosuppressive activity and achieving a sustained response to cell therapy in patients with autoimmune diseases.

\section{References}

1. Sakaguchi S, Miyara M, Costantino CM, Hafler DA. FOXP3 ${ }^{+}$ regulatory $T$ cells in the human immune system. Nat Rev Immunol. 2010; 10 (7): 490-500. DOI:10.1038/nri2785.

2. Venken $\mathrm{K}$, Hellings N, Liblau R, Stinissen P. Disturbed regulatory $T$ cell homeostasis in multiple sclerosis. Trends Mol Med. 2010; 16 (2): 58-68. DOI: 10.1016/j.molmed.2009.12.003.

3. Kravchenko PN, Zhulai GA, Churov AV, Oleinik EK, Oleinik VM, Barysheva OY, et al. Subpopulations of regulatory T-lymphocytes in the peripheral blood of patients with rheumatoid arthritis. Vestnik Rossiiskoi Akademii Meditsinskikh Nauk. 2016; 71 (2): 148-153. DOI: 10.15690/vramn656.

4. Miyara M, Gorochov G, Ehrenstein M, Musset L, Sakaguchi S, Amoura Z. Human FoxP3 ${ }^{+}$regulatory $T$ cells in systemic autoimmune diseases. Autoimmunity Reviews. 2011; 10 (12): 744-55. DOI:10.1016/j.autrev.2011.05.004.

5. Fontenot J, Gavin M, Rudensky A. Foxp3 programs the development and function of $C D 4^{+} \mathrm{CD} 25^{+}$regulatory $\mathrm{T}$ cells. Nature Immunology. 2003; 4 (4): 330-36. DOI: 10.1038/ni904.

6. Nazzal, Gradolatto, Truffault, Bismuth, Berrih-Aknin. Human thymus medullary epithelial cells promote regulatory T-cell generation by stimulating interleukin-2 production via ICOS ligand. Cell Death Dis. 2014; (5): e1420. DOl:10.1038/cddis.2014.37.

7. Famili F, Wiekmeijer A-S, Staal F. The development 719 of T cells from stem cells in mice and humans. Future Science OA. 2017; (3): FSO186. DOI:10.4155/fsoa-2016-0095.

8. Christoffersson G, von Herrath M. Regulatory Immune Mechanisms beyond Regulatory T Cells. Trends in Immunology. 2019; 40 (6): 482-91. DOI:10.1016/j.it.2019.04.005.

9. Desreumaux P, Foussat A, Allez M, Beaugerie L, Hébuterne $X$, Bouhnik $Y$, et al. Safety and efficacy of antigen-specific regulatory
T-cell therapy for patients with refractory Crohn's disease. Gastroenterology. 2012; (143): 1207-17. DOI:10.1053/j. gastro.2012.07.116.

10. Marek-Trzonkowska N, Myśliwiec M, Dobyszuk A, Grabowska M, Derkowska I, et al. Therapy of type 1 diabetes with $\mathrm{CD} 4(+)$ CD25(high)CD127-regulatory $T$ cells prolongs survival of pancreatic islets - results of one year follow-up. Clinical immunology (Orlando, Fla). 2014; (153): 23-30. DOl:10.1016/j. clim.2014.03.016.

11. Bluestone JA, Buckner JH, Fitch M, Gitelman SE, Gupta S, Hellerstein MK, et al. Type 1 diabetes immunotherapy using polyclonal regulatory $\mathrm{T}$ cells. Science translational medicine. 2016; (7): 315ra189. DOI:10.1126/scitransImed.aad4134.

12. Scottà C, Fanelli G, Hoong SJ, Romano M, Lamperti EN, Sukthankar M, et al. Impact of immunosuppressive drugs on the therapeutic efficacy of ex vivo expanded human regulatory T cells. Haematologica. 2016; (101): 91-100. DOI:10.3324/ haematol.2015.128934.

13. Ovcinnikovs V, Ross EM, Petersone L, Edner NM, Heuts F, Ntavli E. CTLA-4-mediated transendocytosis of costimulatory molecules primarily targets migratory dendritic cells. Science Immunology. 2019; 4 (35): eaaw0902. DOl:10.1126/sciimmunol.aaw0902.

14. Arpaia N, Campbell C, Fan X, Dikiy S, Veeken J van der, deRoos P, et al. Metabolites produced by commensal bacteria promote peripheral regulatory T-cell generation. Nature. 2013; (504): 4515. DOI:10.1038/nature12726.

15. Jinek M, Chylinski K, Fonfara I, Hauer M, Doudna JA, Charpentier E. A Programmable Dual-RNA-Guided DNA Endonuclease in Adaptive Bacterial Immunity. Science. 2012; 337 (6096): 816-21. DOI:10.1126/science.1225829. 
16. Okada M, Kanamori M, Someya K, Nakatsukasa H, Yoshimura A. Stabilization of Foxp3 expression by CRISPR-dCas9-based

\section{Литература}

1. Sakaguchi S, Miyara M, Costantino CM, Hafler DA. FOXP3+ regulatory T cells in the human immune system. Nat Rev Immunol. 2010; 10 (7): 490-500. DOI:10.1038/nri2785.

2. Venken $\mathrm{K}$, Hellings N, Liblau R, Stinissen P. Disturbed regulatory T cell homeostasis in multiple sclerosis. Trends Mol Med. 2010; 16 (2): 58-68. DOI: 10.1016/. molmed.2009.12.003.

3. Кравченко П. Н., Жулай Г. Ф., Чуров А. В., Олейник Е. К., Олейник В. М., Барышева О. Ю. и др. Субпопуляции регуляторных Т-лимфоцитов в периферической крови больных ревматоидным артритом. Вестник РАМН. 2016; 71 (2): 148-53. DOI: 10.15690/vramn656.

4. Miyara M, Gorochov G, Ehrenstein M, Musset L, Sakaguchi S, Amoura Z. Human FoxP3 ${ }^{+}$regulatory $T$ cells in systemic autoimmune diseases. Autoimmunity Reviews. 2011; 10 (12): 744-55. DOI:10.1016/j.autrev.2011.05.004.

5. Fontenot J, Gavin M, Rudensky A. Foxp3 programs the development and function of $\mathrm{CD}^{+}{ }^{+} \mathrm{CD} 25^{+}$regulatory $\mathrm{T}$ cells. Nature Immunology. 2003; 4 (4): 330-36. DOI: 10.1038/ni904.

6. Nazzal, Gradolatto, Truffault, Bismuth, Berrih-Aknin. Human thymus medullary epithelial cells promote regulatory T-cell generation by stimulating interleukin-2 production via ICOS ligand. Cell Death Dis. 2014; (5): e1420. DOI:10.1038/cddis.2014.37.

7. Famili F, Wiekmeijer A-S, Staal F. The development 719 of T cells from stem cells in mice and humans. Future Science OA. 2017; (3): FSO186. DOI:10.4155/fsoa-2016-0095.

8. Christoffersson G, von Herrath M. Regulatory Immune Mechanisms beyond Regulatory T Cells. Trends in Immunology. 2019; 40 (6): 482-91. DOl:10.1016/.it.2019.04.005.

9. Desreumaux P, Foussat A, Allez M, Beaugerie L, Hébuterne X, Bouhnik $Y$, et al. Safety and efficacy of antigen-specific regulatory T-cell therapy for patients with refractory Crohn's disease. Gastroenterology. 2012; (143): 1207-17. DOI:10.1053/j. epigenome editing in mouse primary $\mathrm{T}$ cells. Epigenetics Chromatin. 2017; (10): 24. DOI: 10.1186/s13072-017-0129-1.

gastro.2012.07.116

10. Marek-Trzonkowska N, Myśliwiec M, Dobyszuk A, Grabowska M, Derkowska I, et al. Therapy of type 1 diabetes with CD4(+) CD25(high)CD127-regulatory $T$ cells prolongs survival of pancreatic islets - results of one year follow-up. Clinical immunology (Orlando, Fla). 2014; (153): 23-30. DOl:10.1016/j. clim.2014.03.016.

11. Bluestone JA, Buckner JH, Fitch M, Gitelman SE, Gupta S, Hellerstein MK, et al. Type 1 diabetes immunotherapy using polyclonal regulatory $\mathrm{T}$ cells. Science translational medicine. 2016; (7): 315ra189. DOI:10.1126/scitranslmed.aad4134.

12. Scottà C, Fanelli G, Hoong SJ, Romano M, Lamperti EN, Sukthankar M, et al. Impact of immunosuppressive drugs on the therapeutic efficacy of ex vivo expanded human regulatory T cells. Haematologica. 2016; (101): 91-100. DOI:10.3324/ haematol.2015.128934.

13. Ovcinnikovs V, Ross EM, Petersone L, Edner NM, Heuts F, Ntavli E. CTLA-4-mediated transendocytosis of costimulatory molecules primarily targets migratory dendritic cells. Science Immunology. 2019; 4 (35): eaaw0902. DOI:10.1126/sciimmunol.aaw0902.

14. Arpaia N, Campbell C, Fan X, Dikiy S, Veeken J van der, deRoos P, et al. Metabolites produced by commensal bacteria promote peripheral regulatory T-cell generation. Nature. 2013; (504): 451 5. DOI:10.1038/nature12726.

15. Jinek M, Chylinski K, Fonfara I, Hauer M, Doudna JA, Charpentier E. A Programmable Dual-RNA-Guided DNA Endonuclease in Adaptive Bacterial Immunity. Science. 2012; 337 (6096): 816-21. DOI:10.1126/science.1225829.

16. Okada M, Kanamori M, Someya K, Nakatsukasa H, Yoshimura A. Stabilization of Foxp3 expression by CRISPR-dCas9-based epigenome editing in mouse primary $T$ cells. Epigenetics Chromatin. 2017; (10): 24. DOI: 10.1186/s13072-017-0129-1. 